\title{
MicroRNA 574-3p
}

National Cancer Institute

\section{Source}

National Cancer Institute. MicroRNA 574-3p. NCI Thesaurus. Code C127133.

A 22 ribonucleotide sequence that is a final product of the processing of the human MIR574 pre-miRNA. This oligonucleotide may be involved in the negative regulation of gene expression. 